\title{
Population Dynamics of Echinometra mathaei (Echinoidea: Echinodermata) Found on Buleji, Pakistan, North Arabian Sea
}

\author{
Saima Siddique ${ }^{1 *}$ and Zarrien Ayub ${ }^{2}$ \\ ${ }^{1}$ Marine Reference collection and Resource Centre, University of Karachi, \\ Karachi-75270, Pakistan \\ ${ }^{2}$ Centre of Excellence in Marine Biology, University of Karachi, Karachi-75270, \\ Pakistan
}

\section{A B S T R A C T}

The population structure of Echinometra mathaei was studied monthly from May 2011 to November 2012 at a rocky shore of Buleji, Pakistan, Northern Arabian Sea. The test diameter and total weight showed significant temporal variations. The test diameter/wet weight and test height/wet weight relationships followed negative allometry while test height/test diameter showed an isometric relationship. Length-frequency distribution analysis was bimodal in different seasons with the exception of three modes in summer'2012 and one mode in autumn'2012. Estimated parameters of the von Bertalanffy growth functions include growth coeffient $(K)=0.48$ year $^{-1}$, theoretical asymptotic maximum size $(T D \infty)=8.2 \mathrm{~cm}$ and hypothetical age at length zero $\left(\mathrm{t}_{0}\right)=-0.55$ year. The longevity was calculated to be 5.7 years. The natural mortality coefficient was found to be 1.584 year $^{-1}$. Further detailed studies on biological/ecological parameters of E. mathaei are needed for better understanding and management of this species in Northern Arabian Sea.

Article Information
Received 26 September 2018
Revised 22 May 2019
Accepted 13 November 2019
Available online 28 January 2021
Authors' Contribution
ZA supervised this research and
performed all statistical analysis and
interpretation. SS collected samples,
executed laboratory work and wrote
the manuscript.
Key words
Population structure, Growth, Sea
urchin, Pakistan, Northern Arabian
sea

\section{INTRODUCTION}

E chinometra mathaei (Blainville, 1825) is one of the world's most abundant sea urchin distributed both in tropical and sub-tropical zones (Mortensen, 1943; Clark, 1976). This species is found abundantly on a rocky coasts of Pakistan (Tahera, 1993). Echinometra mathaei occupied several types of habitats like, intertidal and sometimes subtidal rocky shores (Nishihira et al., 1991; Hiratsuka and Uehara, 2007) and the coral reefs (Clark, 1976; McClanahan and Muthiga, 1989; Johansson et al., 2013).

The gonads called as "roe" represent the edible part of the sea urchins and are highly priced in the seafood market (Kennedy et al., 2007). The sea urchin fisheries with total global landings of 120,000 metric tonnes reached its peak in 1995, then started declining with global landing of 82,000 metric tonnes in 2012 (Carboni et al., 2012). The decline has been associated to overfishing, lack of proper management and pollution (Keesing and Hall, 1998; Andrew et al., 2002). The species of Echinometra has now been included in the landings of sea urchin, which was not the case earlier because of their smaller size (Rahman et al., 2000).

\footnotetext{
* Corresponding author: saima_siddiq@hotmail.com 0030-9923/2021/0002-0507 \$ 9.00/0

Copyright 2021 Zoological Society of Pakistan
}

Growth studies based on size distributions (Kelso, 1971; Drummond, 1994; Muthiga, 1996), natural growth lines on test plates (Ebert, 1988), tagging experiments (Ebert, 1975) and observations in aquaria (Lawrence and Bazhin, 1998) have been reported in E. mathaei. In general, Echinometra mathaei has a moderate while variable growth as compare to other species of sea urchins (Ebert, 1975). The growth parameters, that is, asymptotic length L $\infty$ and growth coefficient $\mathrm{K}$ of $E$. mathaei have been reported from Hawaii (Ebert, 1975), Western Australia (Ebert, 1982) and Kenya (Muthiga, 1996). The growth was reported to be relatively fast during juvenile stages and became slower as the sea urchin approached the asymptotic size (Lawrence, 2013). The seasonal growth pattern in sea urchins was correlated with algal production and seawater temperatures (Walker, 1981; Tsuda et al., 2006).

The present study was initiated to understand the population structure and growth in sea urchin, E. mathaei found on Buleji, Pakistan. The study will provide baseline data for this species in the Arabian Sea, which can be utilized for its development and management purposes.

\section{MATERIALS AND METHODS}

\section{Study area}

The $1050 \mathrm{~km}$ long coast of Pakistan extends from the Indian border on the south-east to the Iranian border in the north-west (Fig. 1). The Buleji rocky ledge ( $24^{\circ} 50^{\prime} \mathrm{N}$; 
$66^{\circ} 48^{\prime}$ E) on the shore of Karachi (Fig. 1) is a gradually slopping more or less triangular platform, which protrudes out in the Arabian Sea. The ledge is divisible into an exposed area which faces the open sea and is under high wave action and western protected side which is not under direct wave action and is totally submerged on high tides. The coast has elevated and depressed areas, big rocks and boulders in the high tidal zone and varying sizes of tide pools, small boulders, flat rocks and sandy patches in the mid and low tidal zones.

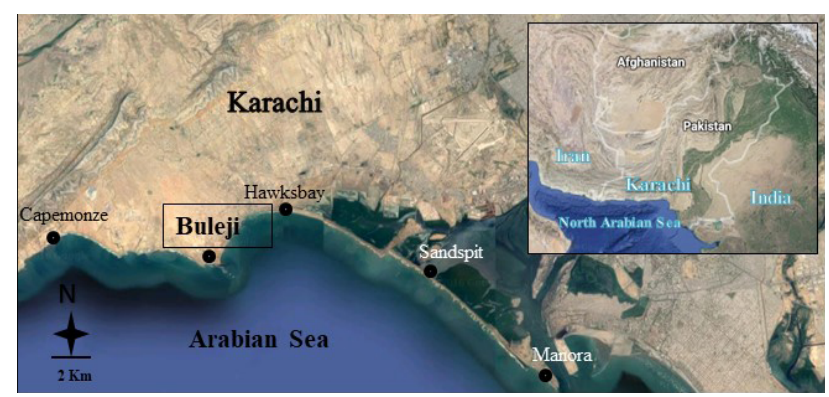

Fig. 1. Map showing the collection site. Scale bar $2 \mathrm{~km}$. Inset shows the coastline of Pakistan.

\section{Sampling and measurements}

Preliminary surveys revealed that the sea urchin, Echinometra mathaei were found hiding in crevices and overhangs only in the low tidal zone of the exposed rocky shore of Buleji. For collection of sea urchins an area of 100 meter in length (parallel to sea) and 10 meter in width was selected in low tidal area and the sampling was done from the same area every month on low tides (-0.1 to $-0.5 \mathrm{~m}$ tide). Sea urchins were distributed haphazardly far from each other in a sampling area so sampling was done randomly and tried to include every size of the sea urchin. Each month approximately 30 individuals of $E$. mathaei were handpicked and brought live in well aerated container to the laboratory. During the study period from April 2011 to November 2012, it was possible to do the sampling of sea urchins for 14 months only, as during June to August (monsoon season) due to roughness of sea, the access to the lowest tidal area was not possible and thus no specimen collected. The specimens were morphologically identified based on the descriptions of Tahera (1993). Various measurements, such as, test diameter (TD), test height (TH) to the nearest $\pm 0.01 \mathrm{~mm}$ and wet weight (WW) to the nearest $\pm 0.01 \mathrm{~g}$ was taken.

\section{Data analysis}

Morphometric relationships

Morphometric (TD, TH, WW) relationships were estimated using equation $\mathrm{Y}=\mathrm{a} \mathrm{X}^{\mathrm{b}}$. The values of a and b were estimated from the $\log _{10}$ transformed values of $\mathrm{X}$ and $\mathrm{Y}$, that is, $\log _{10} \mathrm{Y}=\mathrm{a}+\mathrm{b} \log _{10} \mathrm{X}$ applying a linear regression analysis (Zar, 1996). The Student's t-tests was used to confirm whether $b$ values obtained in the linear regressions were significantly different from the isometric value $(b=1$ or $b=3)$. Temporal variations in the morphometric characters was estimated by one-way ANOVA test $(\alpha=0.05)$. Tukey test (multiple comparison test) was performed to see which months were different. Prior to the analysis the homogeneity of variance was tested by Cochran's test and when needed the data was log-transformed.

\section{Population structure}

The population structure of E. mathaei was analysed monthly, using the Modal Progression Analysis (Gayanillo et al., 2005) where the individual cohorts were separated by using length frequency data based on Bhattacharya's method (Bhattacharya, 1967) with the help of FiSAT II software (Sparre and Venema, 1998)

\section{Growth parameters and longevity}

The theoretical growth parameters, $K$ and $T D \infty$ for E. mathaei was estimated from size frequency data using ELEFAN I by FiSAT II software (Sparre and Venema, 1998) and applied to Von Bertalanffy equation (Von Bertalanffy, 1938) to calculate length (test diameter) at different ages: $T D t=T D \infty\left[1-\mathrm{e}^{-K(t-t o)}\right]$ where $T D t$ is the diameter at age $t, T D \infty$ is the theoretical asymptotic maximum size, $K$ is the growth coefficient, describing the rate at which the asymptotic size (test diameter) is attained, and $t_{0}$ the extrapolated time when size is equal to 0 .

The hypothetical age at length zero $\left(t_{0}\right)$ can be calculated using the $K$ and $L \infty$ values by the formula (Lopez Veiga, 1979): $t_{0}=1 / K * \ln [(T D \infty-T D c) /$ $T D \infty]$ where $K$ is the growth coefficient, $T D \infty$ is the asymptotic length, and $T D c$ is the length at age $\mathrm{t}=0$ or length of recruits.

Longevity of the sea urchins was estimated using the approximation as Longevity $=t_{0}+2.996 / K$ (Pauly, 1983).

The instantaneous natural mortality coefficient (M) was calculated by equation described by Pauly (1980): $\log \mathrm{M}=-0.0066-0.279(\log L \infty)+0.6543(\log K)+$ $0.4634(\log \mathrm{T})$ where $\mathrm{K}=$ growth coefficient $\left(\right.$ year $\left.^{-1}\right)$, $L \infty=$ length asymptotic $(\mathrm{mm})$ and $\mathrm{T}=$ annual mean temperature in the habitat $\left({ }^{\circ} \mathrm{C}\right)$

The data for seasonal variations were compared by considering the periods from November to February and May to September as winter and summer, respectively. The periods between March to April and October are referred to as spring and autumn, respectively. 

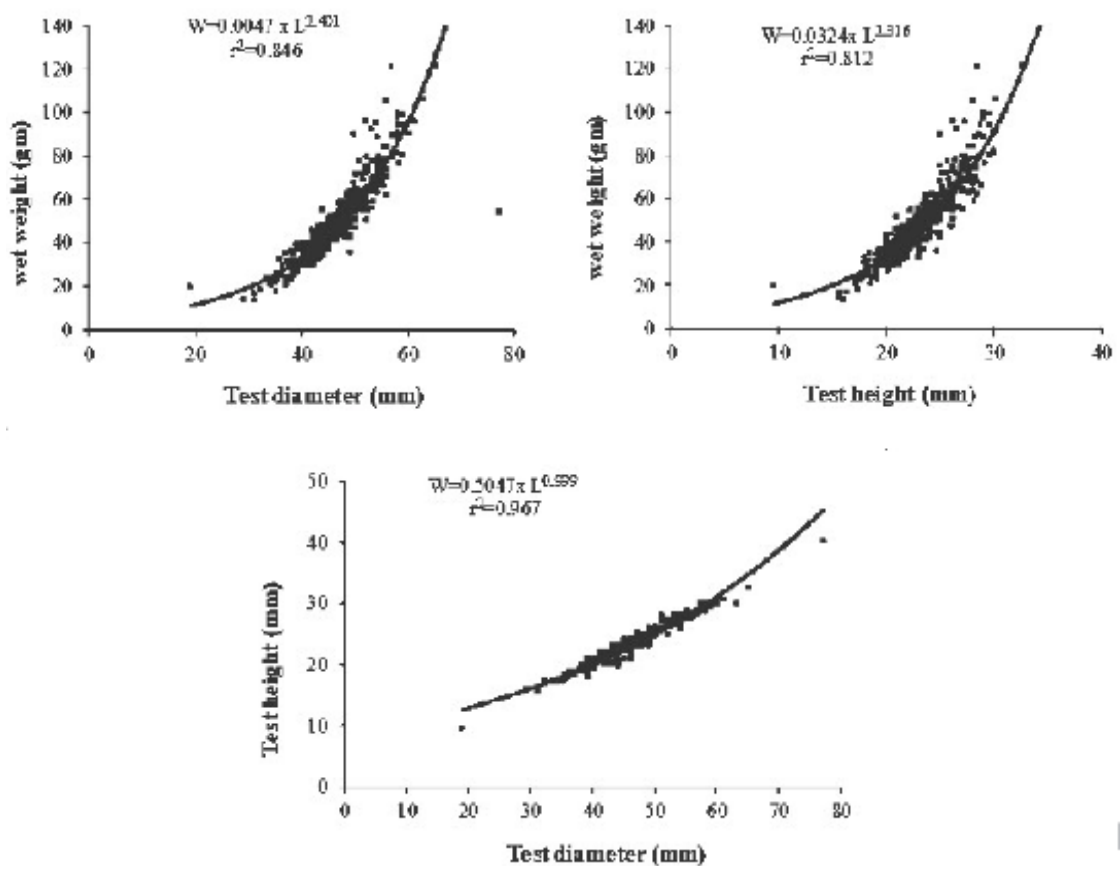

Fig. 2. Relationships between total wet weight -test diameter; total wet weight-test height and test height and test diameter for sea urchin Echinometra mathaei during study period (April 2011-November 2012) at Buleji.

\section{RESULTS}

\section{Morphometric relationships}

The regression equations between test diameter/wet weight and between test height/wet weight showed negative allometry and in these relationships the coefficients of determination $\left(\mathrm{r}^{2}\right)$ were 0.846 and 0.812 , respectively. The test height/test diameter showed an isometric relationship with b value equal to 0.999 (Fig. 2 and Table I).

Table I. Morphometric relationships between total wet weight (WW), test diameter (TD), test height (TH) of the Echinometra mathaei population at Buleji $(\mathrm{N}=391)$.

\begin{tabular}{|c|c|c|c|c|c|c|c|}
\hline Relation & Model & $\mathbf{a}$ & S.E. (a) & b & S.E. (b) & $\mathbf{r}^{2}$ & t-test \\
\hline WW/TD & $\mathrm{WW}=\mathrm{TD}^{\mathrm{b}}$ & 0.005 & 0.086 & 2.401 & 0.052 & 0.846 & $-11.547^{*}$ \\
\hline WW/TH & $\mathrm{WW}=\mathrm{aTH}^{\mathrm{b}}$ & 0.032 & 0.077 & 2.316 & 0.056 & 0.812 & $-12.123 *$ \\
\hline TH/TD & $\mathrm{TH}=\mathrm{aTD}^{\mathrm{b}}$ & 0.505 & 0.016 & 0.999 & 0.009 & 0.967 & $-0.140 *$ \\
\hline
\end{tabular}

\section{Population structure}

A total of 391 individuals of sea urchins were measured during the study period. All the morphometric characters showed significant temporal variations. Temporal variations in test diameter of E. mathaei varied significantly (one-way ANOVA, $\mathrm{F}=4.12, \mathrm{P}<0.01$ ) in
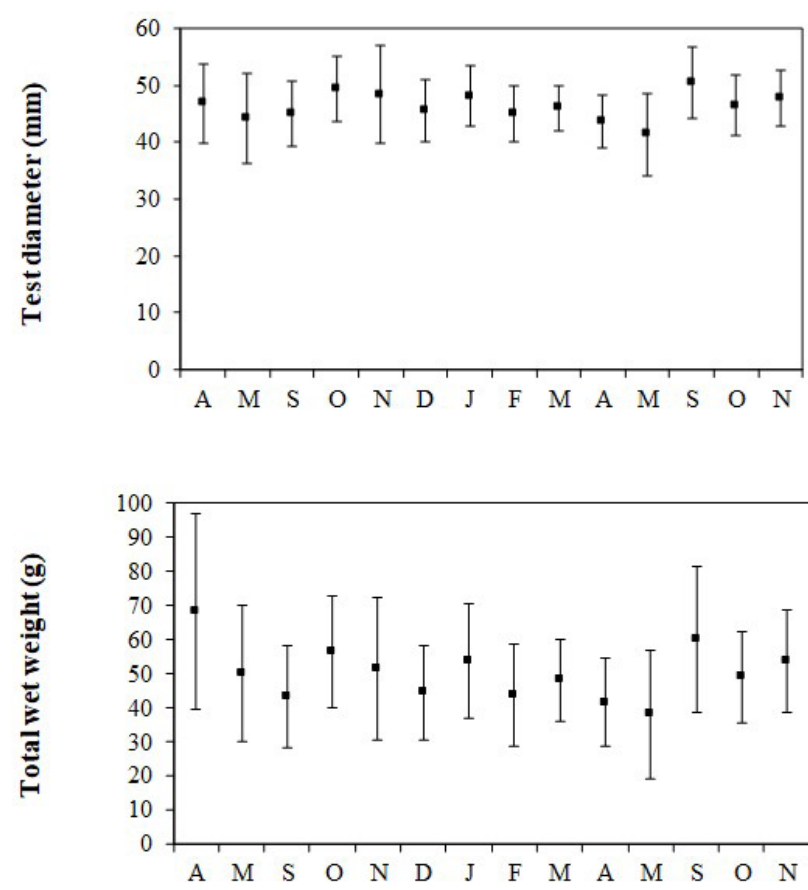

Months

Fig. 3. Temporal variability of the morphometric characters of Echinometra mathaei population from April 2011 to November 2012 at Buleji. 

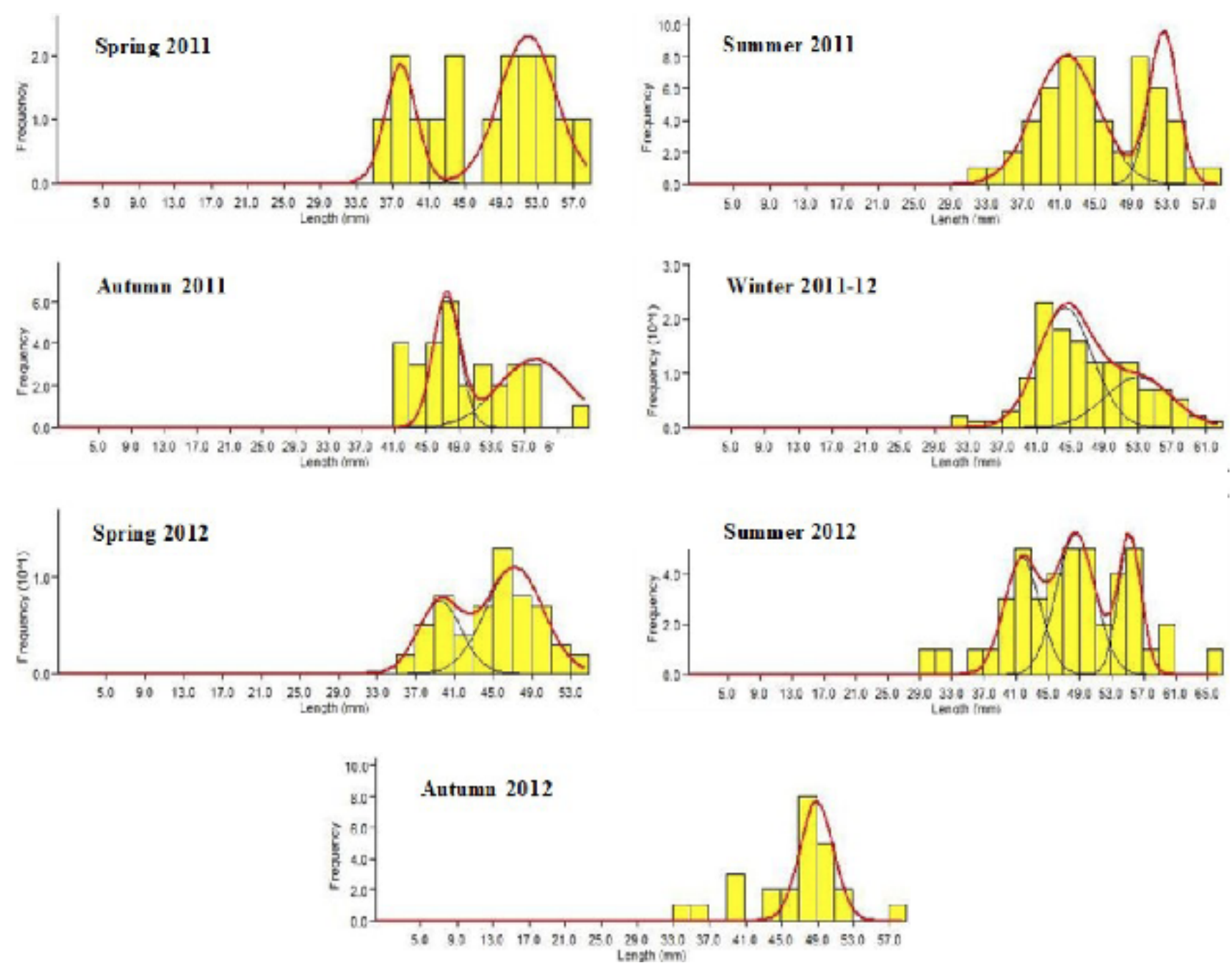

Fig. 4. Modal progression analysis of Echinometra mathaei size-frequency data (thick line) based on Battacharya's method at Buleji.

May'12 and September'12 while wet weight varied significantly (one-way ANOVA, $\mathrm{F}=4.66, \mathrm{P}<0.01$ ) in April'11 and May'12 from rest of the months (Fig. 3).

Length-frequency distribution analysis of E. mathaei was bimodal in different seasons while three modes were found in summer 2012 and one mode in autumn 2012 (Fig. 4). The small-sized individuals of less than $40 \mathrm{~mm}$ were represented by $16.9 \%$ of the population. The mediumsized individuals $(41-50 \mathrm{~mm})$ were $51.1 \%$ and larger-sized individuals $(51-60 \mathrm{~mm})$ were $23.2 \%$ of the population. The larger individuals of greater than $60 \mathrm{~mm}$ were represented by few individuals $(0.8 \%)$ (Fig. 4$)$.

\section{Growth parameters and longevity}

The theoretical growth parameters, $K$ and $\mathrm{T} D \infty$ for E. mathaei estimated from size frequency data using
ELEFAN I by FiSAT software were $0.48 \mathrm{yr}^{-1}$ and 8.2 $\mathrm{cm}$, respectively (Fig. 5). These two parameters were substituted into the equation: $t_{0}=1 / K * \ln [(T D \infty-T D c) /$ $T D \infty]$ with $T D c=1.9 \mathrm{~cm}$ (based on the diameter of the smallest sea urchin acquired by free collection during the period of study) to estimate the $t_{0}=-0.55$ year.

Therefore, growth in sea urchin can be described by the following von Bertalanffy equation:

$$
T D_{t}=8.2\left[1-e^{-0.48(t-(-0.55)}\right]
$$

The longevity was calculated to be 5.7 years. The natural mortality coefficient was found to be $\mathrm{M}=1.584$ year-1.

\section{Age and growth}

The growth in E. mathaei calculated by using von Bertalanffy equation showed that this species attained the 
sizes of $3.2,4.3,5.1,5.8,6.3,6.7,7.0,7.3,7.5,7.6,7.8$, $7.8,7.9,8.0,8.0$ and $8.1 \mathrm{~cm}$ at the age of $1,2,3,4,5,6,7$ and 8 years, respectively at Buleji (Fig. 6).

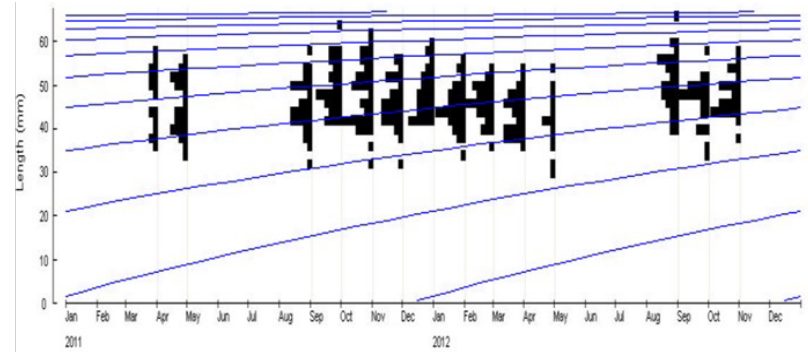

Fig. 5. Length-frequency distribution output from FiSAT with superimposed growth curve for Echinometra mathaei at Buleji. $\mathrm{D} \infty=8.2 \mathrm{~cm}$ (test diameter), $\mathrm{K}=0.48$ year $^{-1}$.

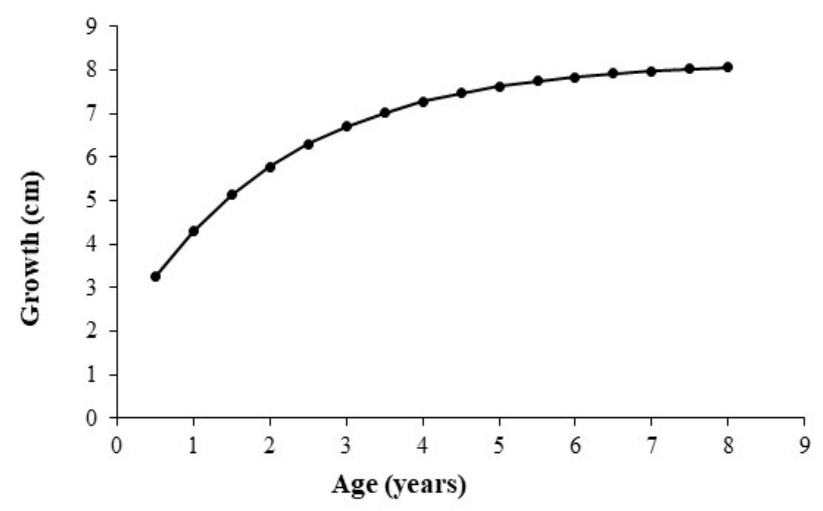

Fig. 6. Von Bertalanffy population model estimates of sizeat-age for Echinometra mathaei at Buleji.

\section{DISCUSSION}

Juveniles less than $20 \mathrm{~mm}$ test diameter of E. mathaei were not found in the present study, probably they were hidden in crevices or get settled usually at shallower depths and when grow larger migrate from these area to join the adult population on the rocky shores. Previous studies for Diadema antillarum in the Caribbean (Bak, 1985) and for $S$. droebachiensis in Northern Norway (Sivertsen and Hopkins, 1995) gave the similar reason about the juveniles. There is another suggestion that the large sized individuals of E. mathaei occupied the most favourable locations forcing the smaller individuals to occupy suboptimal locations (McClanahan and Kurtis, 1991) or smaller individuals are more susceptible to predators and thus avoid comparatively open places, a strategy which is also common in other echinoids in the presence of predators (McClanahan and Kurtis, 1991).
In the present study the longevity in E. mathaei was estimated to be 5.7 years with the maximum size of 7.7 $\mathrm{cm}$, which showed that sea urchins in Pakistan grows more rapidly to a larger size than E. mathaei from Western Australia which attained maximum size of $4.987 \mathrm{~cm}$ in 7 years (Ebert, 1982) and to a size of $8.5 \mathrm{~cm}$ at an age of around 7 years on reefs in Kenya (Muthiga, 1996).

In the present study the $K$ (growth rate) and $T D \infty$ (asymptotic size) for $E$. mathaei were estimated to be 0.48 $\mathrm{yr}^{-1}$ and $8.2 \mathrm{~cm}$ whereas in the same species the $K$ and $T D \infty$ value were $0.292 \mathrm{yr}^{-1}$ and $4.095 \mathrm{~cm}$ from Hawaii (Ebert, 1982). The $T D \infty$ for E. mathaei from different parts of the world was found to range between 4.095 to $5.499 \mathrm{~cm}$ and common growth rate $K=0.322 \mathrm{yr}^{-1}$ (Ebert, 1982). From this it can be concluded that in the present study the estimates of asymptotic size and growth rate were greater than those estimated by Ebert (1982) for the same species in the IndoPacific including Hawaii, Western Australia, Seychelles, Kenya, Israel and Enewetal Atoll. The difference in growth rates and asymptotic size of $E$. mathaei from different parts of the world including Pakistan may be related to factors, such as, food and hydro dynamism which are said to be the main factors determining the growth rate in echinoids (Ebert, 1968; Himmelman, 1986; Muthiga, 1996). The growth in echinoid is also dependent on density (Levitan, 1988). The differences in growth estimates between different studies can also be expected because of the broad geographic range and differences in habitats (Ebert, 1982; Pederson and Johnson, 2007).

The present study provides information on the population structure and growth of sea urchin, E. mathaei on a Buleji rocky shore of Pakistan. These animals in a rocky shores and shallow waters, controls the abundance and distribution of algae and can have profound influence on the structure of benthic communities (Andrew, 1989; Vadas and Elner, 1992; Valentine et al., 1997) rather they play an important role in the dynamics of the entire habitat (Barrett et al., 2009). Therefore, there is a need to monitor the role of sea urchin play on the algal cover of our coast, which can be characterize the pattern of urchin fluctuations in Arabian Sea.

\section{CONCLUSIONS}

Based on the above discussion, we conclude that the present study deliver baseline information on the growth and population structure of sea urchin, Echinometra mathaei on rocky shore of Karachi, Pakistan. The growth rates, asymptotic length and longevity in of E. mathaei was estimated to be greater than reported from the same species in other parts of the world. Therefore, it is concluded that Pakistani sea urchin species has possible potential that 
could be exploited commercially according to scientific outlines. But for further understanding and management of this species advance comprehensive studies on biological/ ecological scale of E. mathaei are required.

Statement of conflict of interest

The authors declare there is no conflict of interest.

\section{REFERENCES}

Andrew, N.L., 1989. Contrasting ecological implications of food limitation in sea urchins and herbivorous gastropods. Mar. Ecol. Progr. Ser., 51: 189-193. https://doi.org/10.3354/meps051189

Andrew, N., Agatsuma, Y., Ballesteros, E., Bazhin, A.G., Creaser, E.P., Barnes, D.K.A., Botsford, L.W., Bradbury, A., Campbell, A., Dixon, J.D., Einarsson, S., Gerring, P.K., Hebert, K., Hunter, M., Hur, S.B., Johnson, C.R., Juino-Menez, M.A., Kalvass, P., Miller, R.J., Moreno, C.A., Palleiro, J.S., Rivas, D., Robinson, S.M.L., Schroeter, S.C., Steneck, R.S., Vadas, R.L., Woodby, D.A. and Xiaoqi, Z., 2002. Status and management of world sea urchin fisheries. Ocean. Mar. Biol. Annu. Rev., 40: 343425. https://doi.org/10.1201/9780203180594.ch7

Bak, R.P.M., 1985. Recruitment patterns and mass mortalities in the sea urchin Diadema antillarum. Proc. $5^{\text {th }}$ Int. Coral Reef Symp., 5: 267-272.

Barrett, N., Buxton, C. and Edgar, G., 2009. Changes in invertebrate and macroalgal populations in Tasmanian marine reserves in the decade following protection. J. exp. Mar. Biol. Ecol., 370: 104-119. https://doi.org/10.1016/j.jembe.2008.12.005

Bhattacharya, C.G., 1967. A simple method of resolution of a distribution into Gaussian components. Biometrics, 23: 115-135. https://doi. org/10.2307/2528285

Carboni, C., Addis, P., Cau, A. and Atach, T., 2012. Aquaculture could enhance Mediterranean Sea urchin fishery, expand supply. Glob. Aqua. Adv., 15: 44-45.

Clark, A.M., 1976. Echinoderms of coral reefs. In: Biology and geology of coral reefs (eds. O.A. Jones and R. Endean). Academic Press, New York. pp. 99-123. https://doi.org/10.1016/B978-0-12395527-2.50010-X

Drummond, A.E., 1994. Aspects of the life history biology of three species of sea urchin on the South African East coast. In: Echinoderms through time (Echinoderms Dijon) (eds. B. David, A. Guille, J.P. Feral and M. Roux) Balkema Press, Rotterdam. pp. 637-641.
Ebert, T.A., 1968. Growth rates of the sea urchin Strongylocentrotus purpuratus related to food availability and spine abrasion. Ecology, 49: 10751091. https://doi.org/10.2307/1934491

Ebert, T.A., 1975. Growth and mortality of post-larval echinoids. Am. Zool., 15: 755-775. https://doi. org/10.1093/icb/15.3.755

Ebert, T.A., 1982. Longevity, life history, and relative body wall size in sea urchins. Ecol. Monogr., 52: 353-394. https://doi.org/10.2307/2937351

Ebert, T.A., 1988. Calibration of natural growth lines in ossicles of two sea urchins, Strongylocentrotus purpuratus and Echinometra mathaei, using tetracycline. In: Echinoderm biology. Proceedings of the sixth international echinoderm conference (eds. R.D. Burke, P.V. Mladenov, P. Lambert and R.L. Parsley). A.A. Balkema Rotterdam, Netherlands. pp. 435-443.

Gayanillo, F.C., Sparre, P., Pauly, D., 2005. FAOICLARM stock assessment tools II (FiSAT II). User's guide. FAO computerized information Series (Fisheries). No. 8, revised version. FAO, Roma, Italia.

Himmelman, J.H., 1986. Population biology of green sea urchins on rocky barrens. Mar. Ecol. Progr. Ser., 33: 295-306. https://doi.org/10.3354/meps033295

Hiratsuka, Y. and Uehara, T., 2007. Feeding ecology of four species of sea urchins (Genus Echinometra) in Okinawa. Bull. mar. Sci., 81: 85-100.

Johansson, C.L., Bellwood, D.R., Depczynski, M. and Hoey, A.S., 2013. The distribution of the sea urchin Echinometra mathaei (de Blainville) and its predators on Ningaloo Reef, Western Australia: The implications for top-down control in an intact reef system. J. exp. Mar. Biol. Ecol., 442: 39-46. https://doi.org/10.1016/j.jembe.2013.01.027

Keesing, J.K. and Hall, K C., 1998. Review of harvests and status of world sea urchin fisheries points to opportunities for aquaculture. J. Shellf. Res., 17: 1597-1604.

Kelso, D.P., 1971. Morphological variation, reproductive periodicity, gamete compatibility and habitat specialization in two species of the sea urchin Echinometra in Hawaii. Ph.D. thesis, University of Hawaii.

Kennedy, E.J., Robinson, S.M.C., Parsons, G.J. and Castell, J.D., 2007. Effect of dietary minerals and pigment on somatic growth of juvenile green sea urchins (Strongylocentrotus droebachiensis). J. World Aquacult. Soc., 38: 36-48. https://doi. org/10.1111/j.1749-7345.2006.00071.x

Lawrence, J.M., 2013. Sea urchins: biology and ecology. 
3rd edition: Elsevier Science. Amsterdam. pp. 380.

Lawrence, J.M. and Bazhin, A., 1998. Life-history strategies and the potential of sea urchins for aquaculture. J. Shell. Res., 17: 1515-1522.

Levitan, D.R., 1988. Density-dependent size regulation and negative growth in the sea urchin Diadema antillarum Philippi. Oecologia, 76: 627-629. https://doi.org/10.1007/BF00397880

Lopez Veiga, E. C., 1979. Fitting von Bertalanffy growth curves in short-lived fish species, a new approach. Invest. Pesq., 43: 179-186.

McClanahan, T.R. and Kurtis, J.D., 1991. Population regulation of the rock boring sea urchin Echinometra mathaei (de Blainville). J. exp. mar. Biol. Ecol., 147: 121-146. https://doi.org/10.1016/00220981(91)90041-T

McClanahan, T.R. and Muthiga, N.A., 1989. Patterns of predation on a sea urchin, Echinometra mathaei (de Blainville), on Kenyan coral reefs. J. exp. mar. Biol. Ecol., 126: 77-94. https://doi.org/10.1016/00220981(89)90125-1

Mortensen, T., 1943. A monograph of the Echinoidea. III, 3. Camarodonta. II. Echinida, Strongylocentrotida, Parasaleniidoe, Echinometridoe. C. A. Reitzel. Copenhagen. pp. 446.

Muthiga, N.A., 1996. The role of early life history strategies on the population dynamics of the sea urchin Echinometra mathaei (de Blainville) on reefs in Kenya. Ph. D thesis, University of Nairobi.

Nishihira, M., Sato, Y., Arakaki, Y. and Tsuchiya, M., 1991. Ecological distribution and habitat preference of four types of Echinometra mathaei on Okinawan coral reef. In: Biology of Echinodermata (eds. T. Yanagisawa, I. Yasumasu, C. Oguro, N. Suzuki and T. Motoka wa). AA Balkema Publishers, Rotterdam. pp. 91-104.

Pauly, D., 1980. On the interrelationships between natural mortality, growth parameters and mean environmental temperature in 175 fish stocks. $J$. Cons. int. Explor. Mer., 39: 175-192. https://doi. org/10.1093/icesjms/39.2.175

Pauly, D., 1983. Some simple methods for the assessment of tropical fish stocks. FAO Fish. Tech. Pap., 234: 52.

Pederson, H.G. and Johnson, C.R., 2007. Growth and age structure of sea urchins (Heliocidaris erythrogramma) in complex barrens and native macroalgal beds in eastern Tasmania. ICES J. mar.
Sci., 65: 1-11. https://doi.org/10.1093/icesjms/ fsm168

Rahman, M.A., Uehara, T. and Aslan, L.M., 2000. Comparative viability and growth of hybrids between two sympatric species of sea urchins (genus Echinometra) in Okinawa. Aquaculture, 183: 45-56. https://doi.org/10.1016/S00448486(99)00283-5

Sivertsen, K. and Hopkins, C.C.E., 1995. Demography of the echinoid Strongylocentrotus droebachiensis related to biotope in northern Norway. In: Ecology offjords and coastal waters (eds. H.R. Skjoldal, C. Hopkins, K.E. Erikstad and H.P. Leinaas). Elsevier Science B.V. Amsterdam. pp. 549-571.

Sparre, P. and Venema, S.C., 1998. Introduction to tropical fish stock assessment. Part 1. Manual. FAO Fishe Tech Pap. 306. 1, Rev. 2. FAO, Rome.

Tahera, Q., 1993. Some economically important regular sea urchins Echinoidea: Coastal zones of Pakistan. In: Proceedings of the national seminar on study and management in coastal zones in Pakistan (eds. N.M. Tirmizi and Q.B. Kazmi). September 2326 1991, Karachi, MRC and UNESCO Pakistan. Karachi. pp. 169-177.

Tsuda, F., Hoshikawa, H., Agatsuma, Y. and Taniguchi, K., 2006. Gonad production of the sea urchin Strongylocentrotus nudus in relation to algal vegetation in shallow waters along the Sea of Japan, southwestern Hokkaido. Japan Sci. Rep. Hokkaido Fish Exp. Stat., 71: 63-68.

Von Bertalanffy, L., 1938. A quantitative theory of organic growth. Human Biol., 10: 181-213.

Vadas, R.L. and Elner, R.W., 1992. Plant-animal interactions in the north-west Atlantic. In: Plantanimal interactions in the marine benthos (eds. D.M. John, S.J. Hawkins and J.H. Price). Clarendon Press, Oxford. pp. 33-60.

Valentine, J.F., Heck, K.L. Jr., Busby, J. and Webb, D., 1997. Experimental evidence that herbivory can increase shoot density in a subtropical turtle grass (Thalassia testudinum) meadow. Oecologia, 112: 193-200. https://doi.org/10.1007/s004420050300

Walker, M.M., 1981. Influence of season on growth of the sea urchin Evechinus chloroticus. N. Z. J. Mar. Freshw. Res., 15: 201-220. https://doi.org/10.1080/ 00288330.1981.9515913

Zar, J., 1996. Biostatistical analysis. Prentice Hall, London. 